\title{
Effects of secondary metabolites from the tropical Brazilian brown alga Dictyota menstrualis on the amphipod Parhyale hawaiensis
}

\author{
Renato C. Pereira $^{1, *}$, Diana N. Cavalcanti ${ }^{1,2}$, Valéria L. Teixeira ${ }^{1}$ \\ ${ }^{1}$ Departamento de Biologia Marinha, Instituto de Biologia, Universidade Federal Fluminense (UFF) CP 100.644, \\ CEP 24001-970, Rio de Janeiro, Brazil \\ ${ }^{2}$ Pós-Graduação em Química Orgânica, Instituto de Química, UFF 24020-150, Niterói, Rio de Janeiro, Brazil
}

\begin{abstract}
Diterpene metabolites produced by Dictyota species are known to inhibit feeding by several herbivorous species. We present the first evidence of feeding-deterrence of dictyotacean metabolites of an unusual compound belonging to a dichotomane diterpene skeleton type. Through experimental assay, we provide evidence of feeding-deterrent properties of lipid-soluble extracts of the Brazilian brown alga D. menstrualis (Hoyt) Schnetter, Hörnig \& Weber-Peukert against the amphipod Parhyale hawaiensis Dana. Bioassay fractionation of this extract revealed the deterrent activity to be due to the diterpenoid (6R)-6-hydroxydichotoma-3,14-diene-1,17-dial, which was found to be the second most abundant metabolite $(\sim 0.2 \%$ dry mass) in $D$. menstrualis. In contrast to other studies, the major diterpenoid pachydictyol A, present as $0.4 \%$ (dry mass) in D. menstrualis, showed no anti-feeding properties. Our results suggest that chemical defense of Dictyota species may vary according to geographic region, thus explaining the presence of a metabolite other than pachydictyol A which functions as the anti-feedant metabolite in $D$. menstrualis from the Brazilian littoral zone.
\end{abstract}

KEY WORDS: Amphipod $\cdot$ Chemical defense $\cdot$ Dictyota menstrualis $\cdot$ Herbivory $\cdot$ Parhyale hawaiensis · Diterpenes

Resale or republication not permitted without written consent of the publisher

\section{INTRODUCTION}

Several chemical studies have indicated that seaweeds produce hundreds of secondary metabolites, including terpenoids (major sesqui- and diterpenes), acetogenins, amino acid-derived compounds, unusual fatty acids, polyphenols (= 'phlorotannins') and metabolites produced through mixed biosynthesis that have terpenoid and phenol portions (Faulkner 1998). Several seaweeds produce large numbers and types of secondary metabolites capable of inhibiting herbivory or which exhibit a wide action against other adverse agents in the marine environment (Hay \& Steinberg 1992, Paul 1992).

*E-mail: egbrecp@vm.uff.br
In the Phaeophyceae of both tropical and warmtemperate marine regions, Dictyota species have been extensively studied and are known to produce secondary metabolites, many of which are broadspectrum feeding deterrents against herbivores. This broad-spectrum action is effected by the well-studied family of structurally similar dictyol diterpenes, including pachydictyol $\mathrm{A}$, dictyol $\mathrm{E}$, dictyol $\mathrm{B}$, dictyol $\mathrm{B}$ acetate, and dictyol $\mathrm{H}$, which have been shown to be active anti-feedant metabolites in ecological assays (see Pereira et al. 1994 for Parhyale hawaiensis and Hay \& Steinberg 1992 for review about remaining herbivore species). Natural concentrations of pachydictyol A, found in some species of Dictyota, can inhibit herbivory by tropical parrotfish species, by the temperate fishes Lagodon rhomboides Linnaeus and Diplobus holbrooki Bean, and by the sea urchin Diadema antil- 
larum Philippi. On the other hand, this same metabolite does not inhibit feeding by the sea urchin Arbacia punctulata (Lamarck) Phillipi, the cosmopolitan polychaete Platynereis dumerilii Audouin and M. Edwards, or the amphipod Parhyale hawaiensis Dana, and has further been shown to increase feeding in the amphipod Ampithoe longimana Smith. Dictyol E reduces herbivory in L. rhomboides, D. holbrooki and Arbacia punctulata, but is not an effective defense against Ampithoe longimana and Platynereis dumerilii. Finally, pachydictyol $\mathrm{A}$, dictyol $\mathrm{B}$, and dictyol $\mathrm{H}$ significantly inhibit herbivory in the rabbitfish Siganus doliatus Cuvier. All these metabolites, collectively referred to as dictyols, represent the only structural class of the prenylated guaiane diterpenes.

Besides the inherent variation in action against herbivores, the presence of seaweed secondary metabolites may vary between tropical (more) and temperate (less) seas, or may exhibit some other type of biogeographic variation. For example, based on a common biogenetic precursor, diterpene metabolites found in Dictyota species belong to 3 different 'chemical groups' which are unequally distributed in the oceans (Teixeira \& Kelecom 1987b). In the Atlantic Ocean, $61 \%$ of the diterpenes found in Dictyota species possess a dolastane (e.g. amijiol) or secodolastane (e.g. isolinearol) skeleton. In contrast, xeniane (e.g. dictyodial) skeletal compounds are more common in the Pacific Ocean, and prenylated guaiane (e.g. pachydictyol A) skeletons have a more cosmopolitan distribution. Finally, within-species variance in secondary metabolite production among different populations of the same species appears to be considerable for some species of seaweeds (Paul \& Fenical 1987, Paul \& van Alstyne 1988) and invertebrates (Sammarco \& Coll 1992).

In this study, we assessed the chemical defenses of Dictyota menstrualis against herbivory by the amphipod Parhyale hawaiensis. A preliminary study of the crude extract of $D$. menstrualis from Brazilian littoral zones indicated that the secondary metabolites present in this species acted as anti-feedant metabolites against crab and amphipod herbivores (Pereira et al. 2000). In contrast, natural concentrations of the well-known pachydictyol A, also found in this species from the Brazilian coast, were not deterrent to the same amphipod species (Pereira et al. 1994). Here we determine what metabolite is responsible for the chemical defense activity previously observed in this algal species.

\section{MATERIALS AND METHODS}

Collection site and organisms. Specimens of Dictyota menstrualis (Hoyt), Schnetter, Höring \& Weber-
Peukert, a common subtidal species, were collected at Enseada do Forno $\left(22^{\circ} 45^{\prime} \mathrm{S}, 41^{\circ} 52^{\prime} \mathrm{W}\right)$, Armação de Búzios (State of Rio de Janeiro, Brazil), during October 1996, in shallow water at a depth of 2.0 to $5.0 \mathrm{~m}$ by snorkeling. This region is characterized by high wave energy and by the presence of the seaweeds Dictyota spp., Sargassum cymosum C. Agardh and S. furcatum Kützing (Yoneshigue 1985). In the upper littoral, the coralline red algae Amphiroa spp. and Jania adherens Lamouroux and the green alga Codium spongiosum Harvey also characterize this region, where the seaurchins Echinometra lucunter Linnaeus and Paracentrotus gaimardii Blainville (Blainville, 1825) are the major invertebrate species (Yoneshigue 1985, Sabino \& Villaça 1999) The amphipod Parhyale hawaiensis Dana is a common invertebrate species, usually found with Sargassum spp., and has been used in previous studies of seaweed chemical defenses in Brazil (e.g. Pereira et al. 1994, Pereira \& Yoneshigue-Valentin 1999). This amphipod is also found in other macroalgal species (e.g. Ulva spp.), but is not closely related to $D$. menstrualis.

Secondary metabolite extraction. A known weight of fresh seaweed tissue (1416 g) was fully extracted with $\mathrm{CH}_{2} \mathrm{Cl}_{2}-\mathrm{MeOH}$ (2:1). Evaporation of the solvent under reduced pressure yielded a brownish residue (22 g, 5.6\% dry wt of the alga), which was subsequently partitioned between n-hexane, $\mathrm{MeOH}$ and $\mathrm{CHCl}_{3}-\mathrm{H}_{2} \mathrm{O}$. The partitions resulted in 3 fractions of different polarities (16.23, 4.03 and $1.46 \mathrm{~g}$, respectively) which were tested in feeding assays. The hexane fraction $(16.23 \mathrm{~g}, 4.17 \%$ dry wt of the alga) exhibited maximum anti-feedant activity compared to the other 2 fractions, and was used in subsequent fractionation. Rapid filtration on silica gel with n-hexane, $\mathrm{CH}_{2} \mathrm{Cl}_{2}$, EtOAc, and $\mathrm{MeOH}$ yielded 4 fractions which were then used in feeding assays. The compounds that eluted with n-hexane (3.06 g) and $\mathrm{CH}_{2} \mathrm{Cl}_{2}$ (3.42 g) were major deterrents against herbivory by the amphipod Parhyale hawaiensis. The compounds that eluted with the $\mathrm{CH}_{2} \mathrm{Cl}_{2}$ fraction were further purified by silica-gel column chromatography (with an eluent of n-hexane, $\mathrm{CHCL}_{3}$, EtOAc, and $\mathrm{MEOH}$, ) which yielded 7 additional fractions. Compounds that eluted with the nhexane fraction contained crude pachydictyol A (250 mg), which was further purified by silica-gel column chromatography (eluent: gradient of $\mathrm{CHCL}_{3}$ in EtOAc) giving pure pachydictyol A (152 mg). The fraction which eluted in $\mathrm{CHCl}_{3}$-EtOAc (9:1) gave crude dichotomane diterpene (545 mg). This fraction was purified by successive preparative TLC eluted with EtOAc in $\mathrm{CHCl}_{3}$ (1:4), giving pure dichotomane diterpene $(60 \mathrm{mg})$. The natural products were identified by comparison of UV, IR, mass, $1 \mathrm{H}-\mathrm{NMR}$ (300MHz, $\mathrm{CDCl}_{3}$ ) and ${ }^{13} \mathrm{C}-\mathrm{NMR}\left(75 \mathrm{MHz}, \mathrm{CDCl}_{3}\right.$ ) with spectral 
data and with previously published data (Blount et al. 1982).

Chemical deterrence assays. The anti-feedant property of all extracts, partitions, fractions, and pure compounds from Dictyota menstrualis were verified by including natural concentrations of these components in an artificial food prepared according to Hay et al. (1994). The artificial food (control) was prepared by adding $0.72 \mathrm{~g}$ of agar in $20.0 \mathrm{ml}$ distilled water and heating in a microwave oven until it boiled. This mixture was added to $16.0 \mathrm{ml}$ cold water containing $2.0 \mathrm{~g}$ freeze-dried Ulva spp. The experimental food (treatment) was similarly prepared, but the fraction or pure compound was first dissolved in diethyl ether, added to the $2.0 \mathrm{~g}$ of freeze-dried Ulva spp., and the solvents then removed by rotary evaporation. This procedure is necessary to obtain a uniform coating of the metabolite on the algal particles prior to their being added to the agar (Hay et al. 1994).

Treatments and controls were hardened onto a screen and cut into small pieces $(7 \times 10$ squares about $1.2 \times 1.4 \mathrm{~mm}$ ) which were then simultaneously offered to Parhyale hawaiensis. Assays were carried out in small plastic receptacles, each containing $250 \mathrm{ml}$ seawater ( $\mathrm{n}=7$ to 38 replicates for each assay; see 'Results'), and 7 individuals of $P$. hawaiensis. The antifeedant activity of secondary metatabolites was esti- mated by comparing the number of squares consumed in both experimental and control foods. New specimens of amphipods were used in each assay (with crude extract, fractions and pure compound).

Statistical analysis. Because paired-samples do not exhibit a normal distribution, the significance of differences in consumption of the experiment and control was evaluated with the Wilcoxon test (Zar 1984).

\section{RESULTS}

Natural concentrations of the crude extract of Dictyota menstrualis significantly deterred feeding by the amphipod Parhyale hawaiensis ( $\mathrm{p}<0.05)$ in laboratory assays (Fig. 1A). Partitions obtained from this crude extract using hexane (I), chloroform (II), and water (III) were also tested as feeding deterrents on $P$. hawaiensis. Of these, both Partitions I and II significantly ( $\mathrm{p}<$ 0.05 and $p=0.05$, respectively) deterred feeding, with Partition I having the most deterrent effect (Fig. 1B). The third fraction (III) did not deter $P$. hawaiensis from feeding ( $p>0.05)$.

As revealed by silica-gel thin-layer chromatography (TLC), both Partitions I and II contained several metabolites in common and were thus combined for subsequent fractionation into 4 new fractions (hexane,
Fig. 1. Feeding on paired control and treatment containing extract of Dictyota menstrualis (A), on semi-purified fractions $(\mathrm{I}=$ hexanic fraction; $\mathrm{II}=$ chloroform fraction; III = aqueous fraction) of this extract (B), on semi-purified fractions ( $\mathrm{HF}=$ hexane; $\mathrm{DF}=$ dichloromethane; $\mathrm{EF}$ $=$ ethyl acetate $\mathrm{MF}=$ methanol) $(\mathrm{C})$, and on pure compounds (6R)-6-hydroxydichotoma-3,14-diene-1,17-dial (a) and pachydictyol A (b) (D). Vertical bars = standard deviations
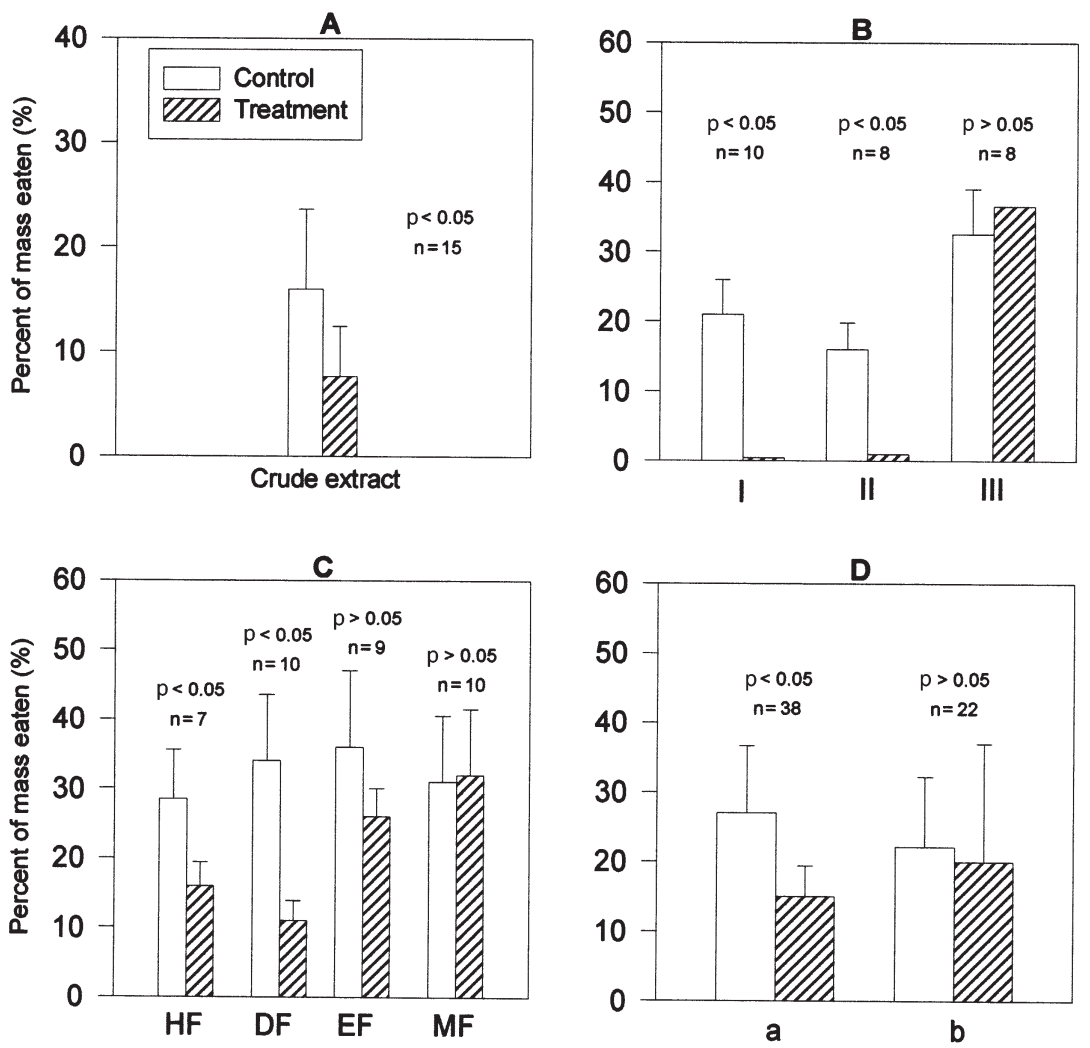


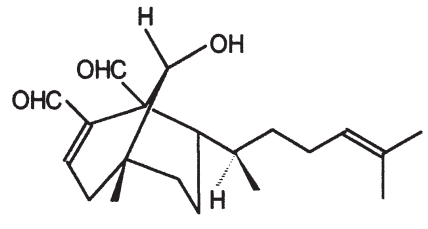

1

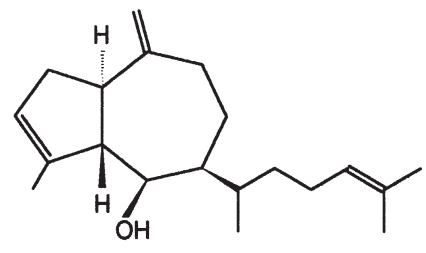

$\underline{2}$

Fig. 2. Dictyota menstrualis. Structures of 2 major diterpenes produced by $D$. menstrualis. (1) (6R)-6-hydroxydichotoma3,14-diene-1,17-dial; (2) pachydictyol A

dichloromethane, ethyl acetate and methanol) which were also tested as feeding deterrents against Parhyale hawaiensis. Both the hexane (HF) and dichloromethane (DF) fractions proved to be significant ( $\mathrm{p}<$ 0.05) anti-feedant metabolites against this amphipod species (Fig. 1C). The remaining fractions, ethyl acetate (EF) and methanol (MF), did not deter herbivory in $P$. hawaiensis (both $\mathrm{p}>0.05$ ). TLC observation enabled isolation of 2 major diterpenoid metabolites (Fig. 2); pachydictyol A (1) ( 0.4\% dry mass, dm) and (6R)-6-hydroxy-dichotoma-3,14-dien1,17-dial (2) ( $0.2 \% \mathrm{dm})$ from the very similar fractions $\mathrm{HF}$ and DF.

Laboratory assays with natural concentrations of these 2 major diterpenoid compounds demonstrated that (6R)6-hydroxy-dichotoma-3,14-dien-1,17-dial significantly inhibited herbivory by Parhyale hawaiensis $(\mathrm{p}<0.05$, Fig. 1D), whereas, pachydictyol A did not $(p>0.05$, Fig. 1D).

\section{DISCUSSION}

This study revealed a specific qualitative difference in the production of secondary metabolites in Dictyota menstrualis from the Brazilian coast compared to the same species from other regions. For example, the major metabolites found in D. menstrualis from North Carolina are the diterpenes pachydictyol A, dictyol E, and dictyodial, which deter consumption by fishes, urchins and amphipods (reviewed by Hay 1996 and Hay \& Steinberg 1992). However, the yields of these compounds appear to vary among collections made at different times and locations, with pachydictyol A being the major metabolite and with dictyol $\mathrm{E}$ present in lesser amounts or vice versa.

We verified that of the 2 most abundant secondary metabolites in the Brazilian Dictyota menstrualis, only the diterpene (6R)-6-hydroxydichotoma-3,14-diene1,17-dial exhibited defensive properties against the amphipod Parhyale hawaiensis. This represents the first evidence of feeding-deterrent properties of dictyotacean metabolites of an unusual compound belonging to the class of dichotomane compounds. This compound, observed in crude extracts (by TLC) of $D$. menstrualis from the Brazilian littoral, is also a defense against herbivory by the crab Pachygrapsus transversus (Pereira et al. 2000). This metabolite has before been reported only in D. dichotoma from Australia (Blount et al. 1982).

In addition, there was no significant anti-feeding effect of pachydictyol A, a major diterpenoid also found in Dictyota menstrualis, which is usually an active chemical defense metabolite in several species of Dictyota (Hay \& Steinberg 1992). In samples from Brazilian waters, preliminary studies have shown that the diterpenoid pachydictyol A was not deterrent against herbivory in the amphipod Parhyale hawaiensis in natural concentrations found in Brazilian D. menstrualis (Pereira et al. 1994). In fact, pachydictyol A was only effective as a defense when offered to this herbivore in concentrations above those found naturally in this algal species.

In general, both in tropical and warm-temperate marine regions, defensive compounds found in Dictyota species belong to a well-studied family of structurally similar dictyol diterpenes such as pachydictyol $\mathrm{A}$, dictyol $\mathrm{E}$, dictyol $\mathrm{B}$, dictyol $\mathrm{B}$ acetate, and dictyol $\mathrm{H}$, which are broadly efficient as a defense against herbivory (Hay \& Steinberg 1992). All these metabolites belong to the structural class (carbon skeleton) of metabolites called prenylated guaiane (Teixeira \& Kelecom 1987a). An exception to this type of skeleton is a dictyodial (xeniane skeleton), also found in $D$. menstrualis together with pachydictyol A and dictyol E (Cronin \& Hay 1996). This dictyodial compound may be a biogenetic precursor of the diterpene (6R)-6-hidroxydichotoma-3,14-diene-1,17-dial, found as a chemical defense in the $D$. menstrualis studied here (Teixeira \& Kelecom 1987a).

Chemical variation, both qualitative and quantitative, may also occur on a habitat scale, whereby green reef-dwelling algae exhibit higher concentrations and a greater variations of secondary metabolites than grass-bed populations (Paul \& Fenical 1986). Investigations have also shown qualitative variation in the metabolites produced by the same seaweed species living in different habitats (Paul \& Fenical 1987, Paul \& van Alstyne 1988). In general, algae growing in areas 
with highest herbivore pressure produce greater concentrations and varieties of secondary metabolites (Paul \& Fenical 1986).

There is also geographic variation in the numbers and types of secondary metabolites produced by seaweeds. For example, the chemical variation, both qualitative (diversity) and quantitative (concentration) of secondary metabolites appears to decrease at higher latitudes in different populations of the same species (Paul \& Fenical 1986, 1987, Paul \& van Alstyne 1988). A recent investigation of geographic patterns in seaweed secondary metabolites showed that tropical algae were less palatable to both a temperate and a tropical urchin than closely related temperate seaweeds, due to quantitative differences between the same compounds (Bolser \& Hay 1996). However, more studies are needed to determine if secondary metabolite production is historically selected by levels of herbivory or by other environmental factors. Although chemical defenses are commonly associated with herbivore abundance and pressure, there have been no studies which conclusively demonstrate that herbivores impose selective pressures on the production of secondary metabolites (van Alstyne \& Paul 1990).

Although plausible, it is difficult to confirm that the biogeographic distribution of secondary metabolites results from evolutionarily different herbivory pressures. Dictyota species from Brazilian littoral zones are very rich in diterpene metabolites. For example, 17 diterpene compounds were found in D. cervicornis from the Brazilian coast (Teixeira et al. 1986a,b, Kelecom \& Teixeira 1988, Fleury et al. 1994). Therefore, we suggest that the Brazilian coast is probably a region rich in Dictyota species that contain high amounts of secondary metabolites.

On a broad scale, a species invasion of new areas results in modification of the relative importance among biogenetic pathways or compounds characteristic of the taxon (Teixeira et al. 1990). However, it is necessary to have a better knowledge of both smallscale and broad-scale variability in the production of Dictyota spp. secondary metabolites to understand the general evolution and ecology (e.g. biogeographic) of chemical defenses in marine environments.

Acknowledgements. National Brazilian Research Council (CNPq, PADCTII-QEQ, Proc. 62.0470/94.1) and FAPERJ (Proc. E-26/170.881/96) supported this research. R.C.P. and V.L.T. thank CNPq for the Research Productivity Fellowships (Proc. 521914/96-5 and 303016/90-6, respectively). D.N.C. gratefully acknowledge CAPES for providing MSc Fellowships. Mark E. Hay provided the pachydictyol A standard that helped us to interpret TLC plates of Dictyota menstrualis extract and fractions. The comments by Joel Creed, Greg McFall and 3 anonymous referees improved the manuscript.

\section{LITERATURE CITED}

Blount JF, Dunlop RW, Erickson KL, Wells RJ (1982) Two diterpenes with new carbocyclic ring systems from an Australian collection of the brown alga Dictyota dichotoma. Aust J Chem 35:145-163

Bolser RC, Hay ME (1996) Are tropical plants better defended? Palatability and defenses of temperate vs tropical seaweeds. Ecology 77:2269-2286

Cronin G, Hay ME (1996) Induction of seaweed chemical defenses by amphipod grazing. Ecology 77:2287-2301

Faulkner DJ (1998) Marine natural products. Nat Prod Rep 15: 113-158

Fleury BG, Kelecom A, Pereira RC, Teixeira VL (1994) Polyphenols, terpenes and sterols in Brazilian Dictyotales and Fucales (Phaeophyta). Bot Mar 37:457-462

Hay ME (1996) Marine chemical ecology: what's known and what's next? J Exp Mar Biol Ecol 200:103-134

Hay ME, Steinberg PD (1992) The chemical ecology of plantherbivore interactions in marine versus terrestrial communities. In: Rosenthal JA, Berenbaum MR (eds) Herbivores: their interactions with secondary metabolites, evolutionary and ecological processes. Academic Press, San Diego, p 371-413

Hay ME, Kappel QE, Fenical W (1994) Synergisms in plant defenses against herbivores: interactions of chemistry, calcification, and plant quality. Ecology 75:1714-1726

Kelecom A, Teixeira VL (1988) Dolastane diterpenes from the marine brown alga Dictyota cervicornis. Phytochemistry 27:2707-2709

Paul VJ (1992) Ecological roles of marine natural products. Comstock Publ. Associates, Cornell University Press, Ithaca

Paul VJ, Fenical W (1986) Chemical defense in tropical green algae, order Caulerpales. Mar Ecol Prog Ser 34:157-169

Paul VJ, Fenical W (1987) Natural products chemistry and chemical defense in tropical marine algae of the phylum Chlorophyta. Bioorg Mar Chem 1:1-29

Paul VJ, van Alstyne KL (1988) Chemical defense and chemical variation in some tropical Pacific species of Halimeda (Halimedaceae; Chlorophyta). Coral Reefs 6:263-269

Pereira RC, Teixeira VL, Kelecom A (1994) Chemical defenses against herbivores in marine algae. 1. The brown alga Dictyota dichotoma (Hudson) Lamouroux from Brazil. Anais Acad Bras Ciênc 66:229-235

Pereira RC, Yoneshigue-Valentin Y (1999) The role of polyphenols from tropical brown alga Sargassum furcatum on the feeding by amphipod herbivores. Bot Mar 42:441-448

Pereira RC, Donato R, Teixeira VL, Cavalcanti DN (2000) Chemotaxis and chemical defenses in seaweed susceptibility to herbivory. Rev Bras Biol 60:405-414

Sabino CM, Villaça R (1999) Estudo comparativo de métodos de amostragem de comunidades de costão. Rev Bras Biol 59:407-419

Sammarco PW, Coll JC (1992) Chemical adaptations in the Octocorallia: evolutionary considerations. Mar Ecol Prog Ser 88:93-104

TeixeiraVL, Kelecom A (1987a) A chemotaxonomic study of diterpenes from the marine brown algae of the genus Dictyota. Sci Total Environ 75:271-283

Teixeira VL, Kelecom A (1987b) Geographic distribution of the diterpenes from the marine brown alga Dictyota Lamouroux. Nerítica 2:179-200

Teixeira VL, Tomassini T, Fleury BG, Kelecom A (1986a) Dolastane and secodolastane diterpene from the marine brown alga Dictyota cervicornis Kützing. J Nat Prod 49: 570-575 
Teixeira VL, Tomassini T, Kelecom A (1986b) Cervicol, a further secodolastane diterpene from the brown marine alga Dictyota cervicornis Kützing (Phaeophyceae, Dictyotales). Bull Soc Chim Belg 95:263-268

Teixeira VL, Almeida SAS, Kelecom A (1990) Chemosystematic and biogeographic studies of the diterpenes from the marine brown alga Dictyota dichotoma. Biochem Syst Ecol 18:87-92

van Alstyne KL, Paul VJ (1990) The biogeography of polyphe-

Editorial responsibility: Otto Kinne (Editor),

Oldendorf/Luhe, Germany nolic compounds in marine macroalgae: temperate brown algal defenses deter feeding by tropical herbivorous fishes. Oecologia 84:158-163

Yoneshigue Y (1985) Taxonomie et ecologie des algues marines dans la région de Cabo Frio (Rio de Janeiro, Brésil). Thèse Doctorat-ès-Sciences, Faculté de Luminy, Université Aix-Marseille II

Zar JH (1984) Biostatistical analysis, 2nd edn. Prentice-Hall Inc, Englewood Cliffs, NJ

Submitted: September 17, 1999; Accepted: April 4, 2000

Proofs received from author(s): September 5, 2000 